\title{
Application of Empty Oil Palm Bunches as CMC to Prevent Loss Circulation
}

Idham Khalid $^{1 *}$, Novia Rita ${ }^{1}$, Muhammad Ridho Efras ${ }^{1}$

${ }_{1}^{1}$ Department of Petroleum Engineering, Faculty of Engineering, Universitas Islam Riau, Jl. Kaharuddin Nasution No. 113, Pekanbaru, Riau Province, Indonesia - 28284

*Corresponding Author: khalididham@eng.uir.ac.id

\begin{tabular}{l}
\hline Article History: \\
\hline Received: November 18, 2019 \\
Receive in Revised Form: May 5, 2021 \\
Accepted: May 21, 2021 \\
\hline
\end{tabular}

Keywords:

Carboxymethyl Cellulose (CMC), Energy Dispersive X-ray Spectroscopy (EDS), empty oil palm bunches

\begin{abstract}
Drilling is an activity carried out to obtain the desired target. Furthermore, drilling mud a very significant material involved in the drilling process, and must, therefore, obtain a rational value from the rheology. A suitable technique to achieve this goal is the use of additives, for instance, Carboxymethyl Cellulose (CMC) to improve the viscosity and air binding. This study, therefore, uses CMC produced from organic oil palm bunches as an alternative for industrial CMC. CMC of Oil Palm Empty Bunches have been tested by Energy Dispersive X-ray Spectroscopy (EDS) to determine its composition. The Empty Oil Palm Oil which uses Tenera type was taken from Riau Province, Rokan Hulu Regency, Kunto Darussalam District. In this study, this experiment used CMC Empty Oil Palm and industrial CMC to find the value of viscosity, plastic thickness, melting point, gel strength, mud cake, and filtering volume of drilling mud and prevent the loss circulation with adding each CMC composition to mud samples with amount of $2 \mathrm{gr}, 4 \mathrm{gr}, 6 \mathrm{gr}, 8 \mathrm{gr}$ and 10 gr. According to the EDS analysis, the Carbon (C) and Oxygen (0) content of CMC from empty oil palm bunches were $58.85 \%$ and $41.15 \%$, respectively. In addition, the industrial standard for plastic viscosity and yield point were not attained by using $8 \mathrm{gr}$ and $10 \mathrm{gr}$ of this CMC.
\end{abstract}

\section{INTRODUCTION}

Drilling is an operation performed to get attain the desired target, and drilling mud is one of the strategies to achieve the target. Furthermore, drilling mud affects work safety, efficiency, drilling speed, as well as drilling costs, and is, therefore, a very significant material in drilling operations. The physical properties of drilling mud must always be controlled, to enable proper functioning (Maulana, 2017).

In this study, Carboxymethyl Cellulose (CMC) was used to bind water and increase the mud thickness, to prevent loss circulation. According to Rubiandini (2010), CMC is an effective additive for preventing fluid loss in a variety of water-based muds. CMC is also a suitable agent for filtration loss reduction, shale control, and viscosifying mud rheology (Luqman Arif, Aris Buntoro, Sudarmoyo, 2001).

Currently, organic materials are being used in industries, for instance, bagasse ash for drilling cement and preventing loss circulation (Herawati \& Rita, 2017), as well as cocoa pod skin and empty oil palm bunches, as CMC materials (Tati Fatimah, 2016).

The use of empty oil palm fruit bunches as raw material to manufacture CMC, as a drilling mud additive, is currently unexploited in the oil world, especially within Riau, the largest palm oil-producing region in Indonesia. In 2015, Riau's oil palm plantations had a total area of 2,400,875 hectares and produced $8,059,846$ tons/year (Ditjen Perkebunan, 2017). Therefore, researchers suggested using oil palm empty fruit bunches to manufacture CMC as a substitute for industrial CMC additive, and to study the substitute's effect on the rheology of drilling mud. The oil palm bunches used in this study were collected from Rokan Hulu Regency, Riau Province. 
Based on the results, the empty oil palm bunches comprised $50.29 \%$ cellulose, $25.54 \%$ hemicellulose, and 24.15\% lignin (Richana et al., 2011). This composition indicates Oil Palm Empty Bunches are suitable raw materials for manufacturing $\mathrm{CMC}$ as an additive to regulate the rheology of drilling mud, in place of industrial CMC. In this study, the drilling mud rheology parameters analyzed include viscosity, plastic viscosity, yield point, gel strength, mud cake, and volume filtration loss.

\section{METHODS}

The first step in this study was to prepare the equipment and materials. The main material used was empty oil palm fruit bunches. Figure 1 shows a flow chart of the CMC synthesis carried out using the method described by Hong (2013), while Table 2 shows all the materials used in this experiment.

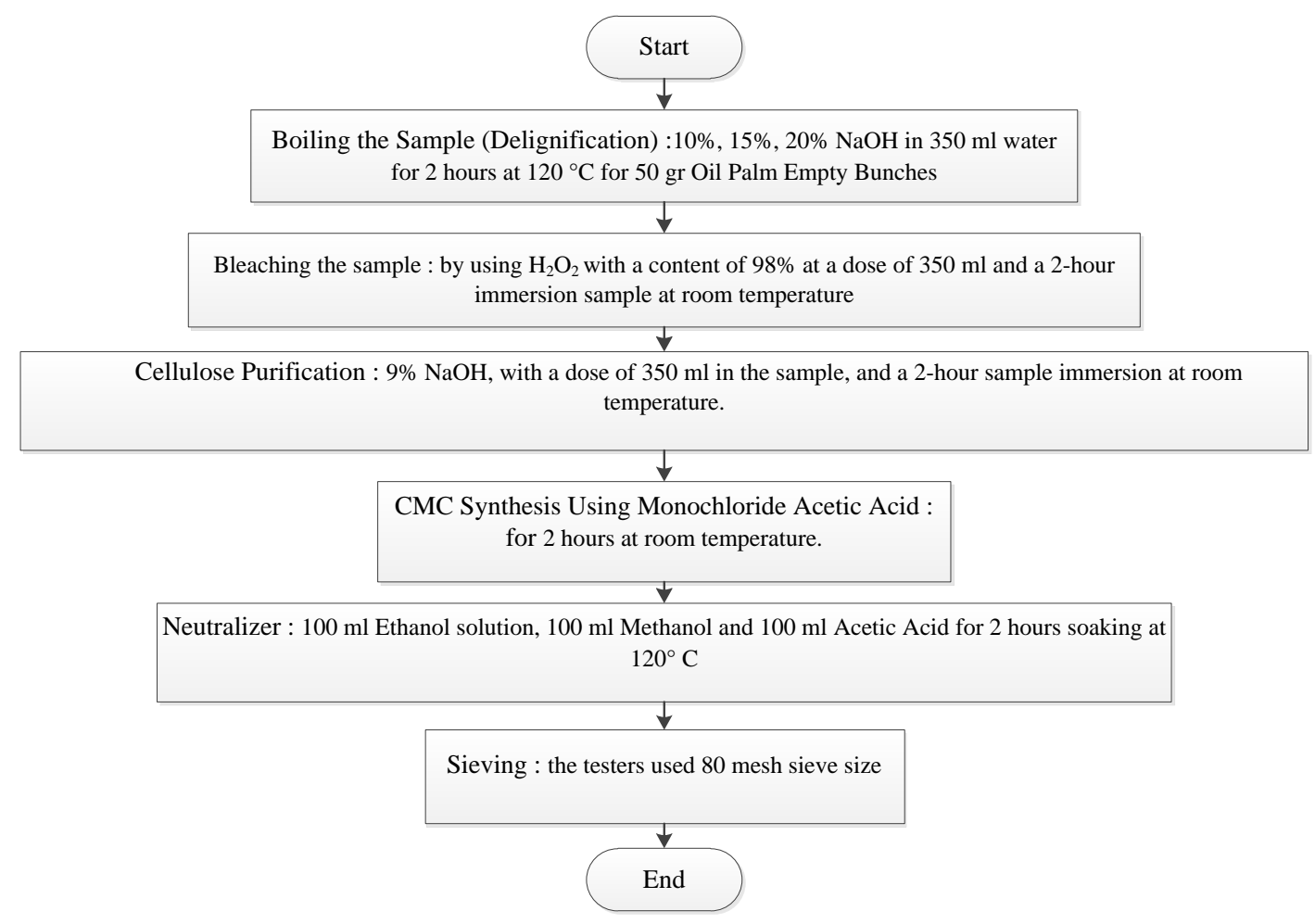

Figure 1. Synthesis of CMC from empty oil palm fruit bunches.

Table 1. Materials

\begin{tabular}{cc}
\hline \multicolumn{2}{c}{ Element } \\
\hline $\mathrm{NaOH}$ & Ethanol \\
CMC Oil Palm Empty Bunches & Methanol \\
$\mathrm{H}_{2} \mathrm{O}_{2}$ & Acetic Acid \\
$\mathrm{NaOH}$ & Water and Bentonite \\
Monochloride Acetic Acid & CMC Industry \\
\hline
\end{tabular}

In addition, mud was prepared using in the laboratory using the method described by Harry et al (2017) outlined below.

1. A measuring glass was prepared.

2. $350 \mathrm{ml}$ of water was poured into the glass.

3. A 220 -volt mixer was prepared to mix the ingredients in the following ratio.
a. Water
: $350 \mathrm{ml}$
b. Bentonite
$: 22.5 \mathrm{gr}$ 

c. CMC from empty oil palm bunches
$: 2,4,6,8$ and $10 \mathrm{gr}$
d. Industrial CMC
$: 2,4,6,8$ and $10 \mathrm{gr}$

4. A Marsh funnel was prepared to measure the mud's flow rate.

5. The VG meter was prepared to carry out the following measurements.
a. Plastic viscosity
b. Yield point
c. Gel strength in 10 seconds and 10 minutes

6. The filter press was prepared to carry out the following measurements.
a. Mud cake value
b. The volume of filtration loss

\section{RESULT AND DISCUSSION}

\section{A comparison of mud rheology between CMC from empty oil palm fruit bunches and industrial CMC}

Energy-dispersive $\mathrm{x}$-ray spectroscopy (EDS) is a method used to determine a sample's composition or constituent elements (Ailin et al., 2017). The oil Palm Empty Bunches used in this study were the palm oilrich tenera bunches, collected from Riau Province, Rokan Hulu Regency, Kunto Darussalam District. Subsequently, the bunches were processed into CMC and used as an additive for drilling mud, in comparison with industrial CMC.

Table 2 shows the composition of CMC from empty oil palm fruit bunches based on the EDS analysis.

Table 2. The EDS test of CMC from empty oil palm fruit bunches

\begin{tabular}{cc}
\hline Element & Mass Percentage (\%) \\
\hline C & 58.85 \\
0 & 41.15 \\
Total & 100 \\
\hline
\end{tabular}

According to Table 2, CMC from empty oil palm fruit bunches comprises two elements, Carbon and Oxygen, at percentages of $58.85 \%$ and $41.41 \%$, respectively. Therefore, CMC from empty oil palm fruit bunches was concluded to have high carbon content, and this indicates the high polysaccharide (cellulose) content of empty oil palm fruit bunches (Prabawati \& Wijaya, 2008).

\section{Visccosity}

The mud viscosity was measured using a marsh funnel, by determining the flow time with a stopwatch. Figure 2 shows the viscosity of all the samples. Based on Figure 2, CMC from empty oil palm fruit bunches has almost the same viscosity as the industrial counterpart. CMC from empty oil palm fruit bunches had viscosities of $605,1035,1502,2283$, and 3086 seconds for the $2,4,6,8$, and 10 gr samples, respectively. Meanwhile, industrial CMC has viscosities of $802,1081,1560,2364$, and 3144 seconds, for the 2, 4, 6, 8, and 10 gr samples, respectively. These values are categorized as high viscosity, due to the ability of empty oil palm fruit bunch CMC to bind water and Bentonite. The viscosity of mud mixed with this CMC is thick. CMC increases the viscosity of drilling fluid (Hall et al., 2017). This is similar to the report by Kafashi et al (2017), where CMC obtained from CMC improved the viscosity of drilling fluid by up two times, thus, reducing loss circulation 


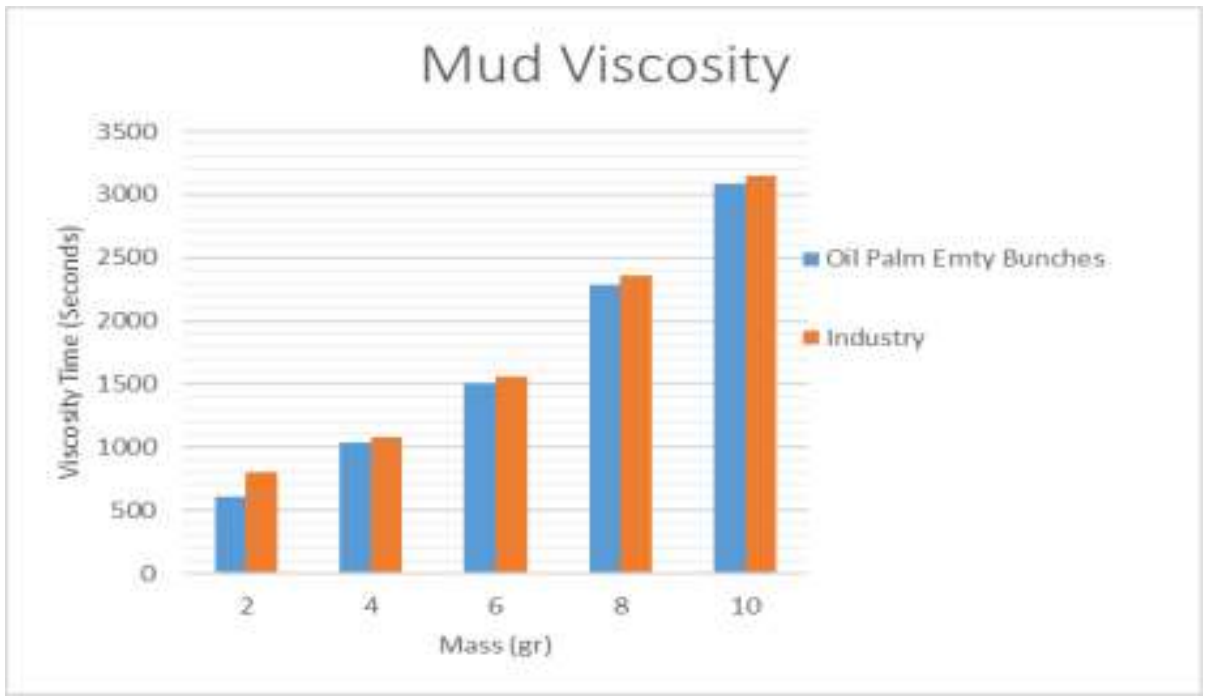

Figure 2. The visosity charts of industrial CMC and CMC from empty oil palm fruit bunches.

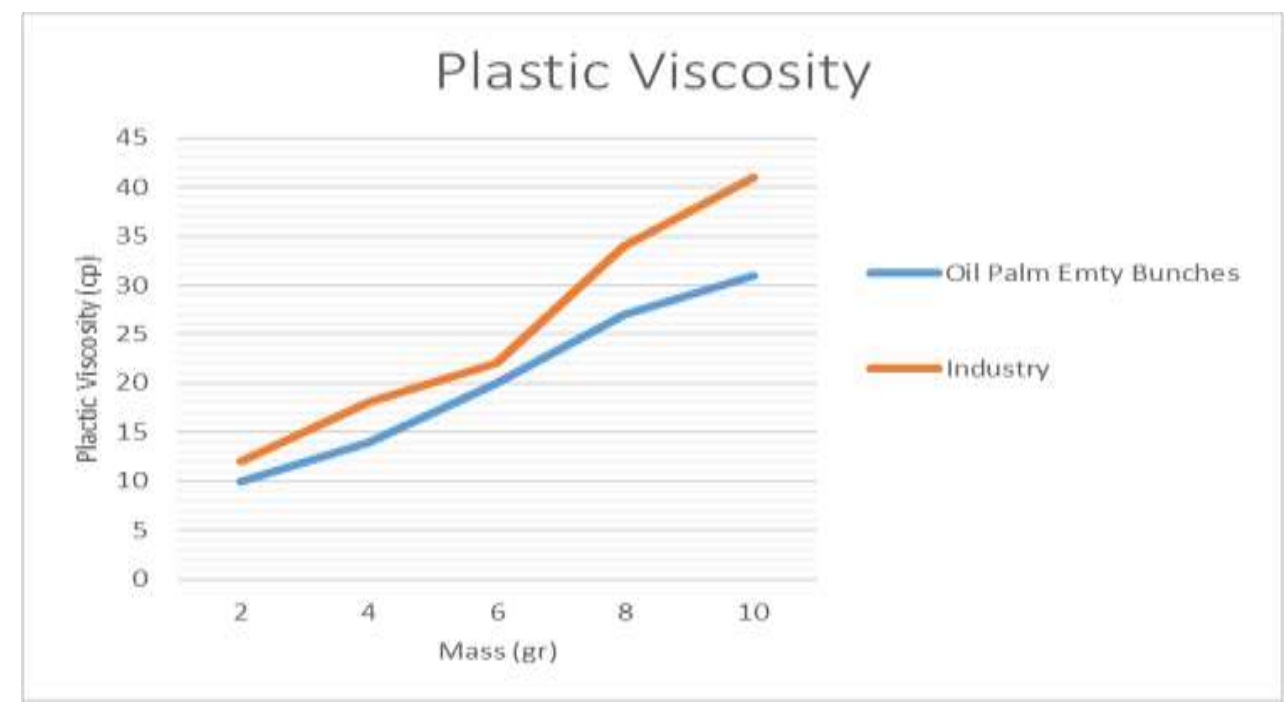

Figure 3. The plastic viscosity charts of industrial CMC and CMC from empty oil palm fruit bunches

\section{Plastic viscosity}

According to Luqman Arif et al (2001) , plastic viscosity is often described as part of the resistance to flow caused by mechanical friction. Figure 3 shows the plastic viscosity of all the samples.

Based on the graph in Figure 3, drilling mud samples containing CMC from empty oil palm fruit bunches were only able to match the industrial counterparts in the 2, 4, and 6 gr samples, with a range of 2-4 cp below the industrial counterparts. However, the 8 and 10 gr samples of CMC from empty oil palm fruit bunches had values 7 and $10 \mathrm{cp}$ lesser, respectively, compared to the industrial counterparts. CMC from empty oil palm fruit bunches had plastic viscosities of 10,14,20, 27, and $31 \mathrm{cp}$, for the 2, 4, 6, 8, and $10 \mathrm{gr}$ samples, respectively. Meanwhile, industrial CMC had plastic viscosities of 12, 18, 22, 34, and $41 \mathrm{cp}$, for the $2,4,6,8$, and $10 \mathrm{gr}$ samples, respectively. In addition, the average difference in plastic viscosity between the industrial and empty oil palm fruit bunch CMCs is $1.04 \%$. High plastic viscosity and solids content are influenced by the size of the solids, thus, a rise in the solid content leads to a rise in the mud viscosity (Luqman Arif et al., 2001). A report by Gao (2016) stated a $1 \mathrm{~g}$ rise in the concentration of CMC from Welan Gum (Organic) has the capacity to plastic viscosity by $10 \mathrm{cp}$, and consequently, reduce loss circulation.

\section{Gel Strenght}

Good drilling mud must be able to withstand cutting and mud ballast material, to ensure the mud does not fall and settle at the bottom of the borehole, after drilling. Figure 4 shows the gel strength of all the samples. 


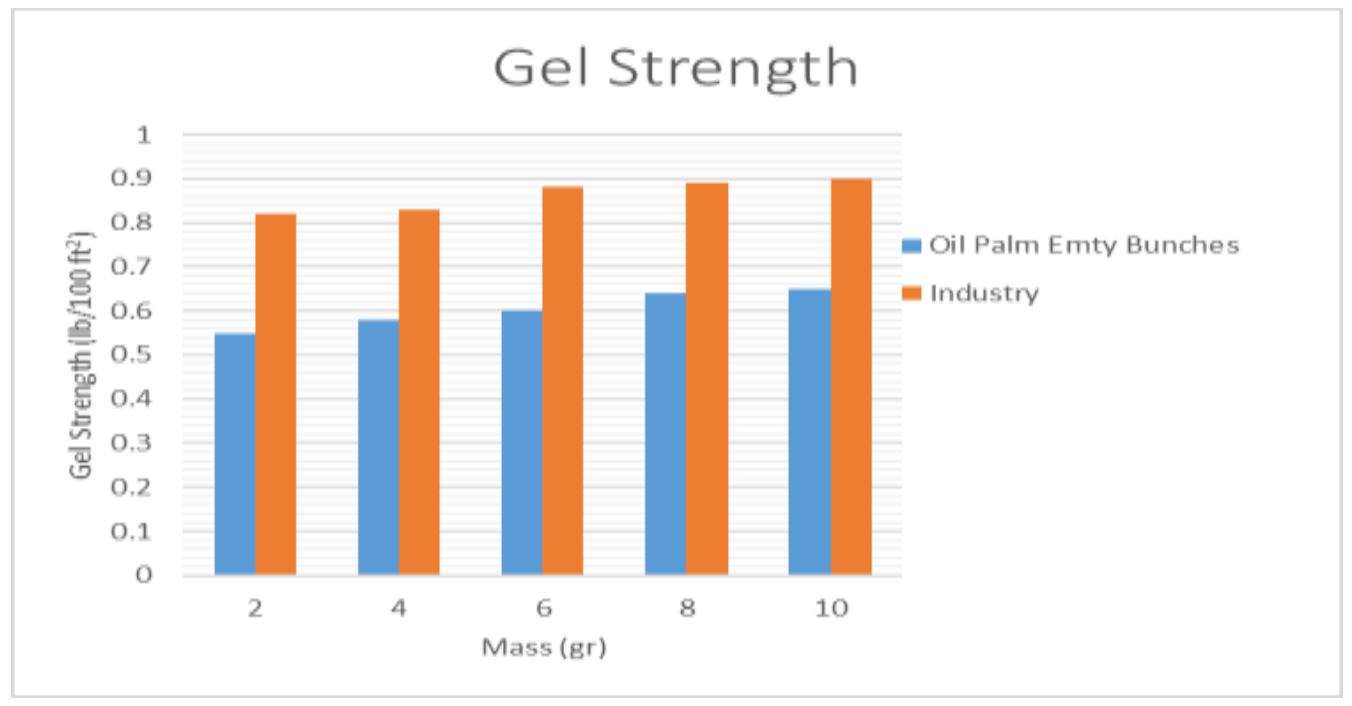

Figure 4. The Gel Strength of mud samples containing industrial CMC and CMC from empty oil palm fruit bunches

Figure 4 shows the impact of each quantity of $\mathrm{CMC}$ additive. Based on the graph, the gel strength of mud samples containing industrial CMC and CMC from empty oil palm fruit bunches, were not much different. Mud samples containing CMC from empty oil palm fruit bunches had gel strengths of $0.54 \mathrm{lb} . / 100 \mathrm{ft}^{2}, 0.57$ lb./100 ft' $0.6 \mathrm{lb} . / 100 \mathrm{ft}^{2}, 0.66 \mathrm{lb} . / 100 \mathrm{ft}^{2}$ and $0.67 \mathrm{lb} . / 100 \mathrm{ft}^{2}$, for 2, 4, 6, 8, and $10 \mathrm{gr}$ of additive, respectively. Meanwhile, the industrial counterparts had gel strengths of $0.82 \mathrm{lb} . / 100 \mathrm{ft}^{2}, 0.83 \mathrm{lb} . / 100 \mathrm{ft}^{2}$, $0.87 \mathrm{lb} . / 100 \mathrm{ft}^{2}, 0.89 \mathrm{lb} . / 100 \mathrm{ft}^{2}$ and $0.9 \mathrm{lb} . / 100 \mathrm{ft}^{2}$, for 2, 4, 6, 8, and $10 \mathrm{gr}$ of additive, respectively.

A comparison of the two sets of values shows the addition of both CMC samples increases the mud's gel strength. Therefore, CMC from empty oil palm fruit bunches was concluded to meet the standards for industrial CMC. This means CMC from empty oil palm fruit bunches is a suitable replacement for the industrial counterpart, to sustain cutting in the borehole, without falling or settling at the bottom. A study by Inemugha et al (2019) reported an increase in gel strength with the increase in the content of CMC from Terminalia Mantaly Exudate and consequent prevention of loss circulation.

\section{Mud Cake}

Mud cake is formed in cases where drilling mud meets formation water, then attaches to the permeable rock and solidifies. Consequently, the borehole diameter becomes narrower in this section (Amin, 2017). Figure 5 shows the mud cake charts of all the samples. Figure 5 shows the impact of each quantity of CMC additive. Based on the diagram, the mud cake formed with CMC from empty oil palm fruit bunches is higher, compared to the industrial counterparts. According to Grahadiwin et al (2016), CMC from empty oil palm fruit bunches is thicker, compared to the industrial counterpart. A good mud cake ought to have a thickness below $1.5 \mathrm{~mm}$. Based on the graph above, both CMCs produced mud cakes below $1.5 \mathrm{~mm}$ thick. Therefore, CMC from empty oil palm fruit bunches met the standards of Industrial CMC. Al-Hameedi et al. (2019) reported the use of $5 \mathrm{gr}$ of $\mathrm{CMC}$ from Carton plus $4.5 \mathrm{gr}$ of Na2CO3 increased the thickness of mud cake by almost over $0.3 \mathrm{~cm}$, from 0.19 and $0.214 \mathrm{~cm}$ to $0.54 \mathrm{~cm}$, at a concentration of $1 \%$ (10 gr) and $2 \%$ (20 gr) of CMC.

\section{Filtration Loss Volume}

Filtration loss is the loss of some liquid phase (filtrate) mud entering the permeable formation. Figure 6 shows the filtration loss volume of all mud samples. Extreme filtration loss has a negative effect on the formation and the mud. This has the capacity to cause formation damage, leading to severe liquid loss from the mud. A higher CMC content leads to lower mud filtrate volume, indicating a lower filtration loss. Based on Figure 6, the filtration volume of mud samples containing industrial CMC and CMC from empty oil palm fruit bunches are not much different. The addition of CMC from empty oil palm fruit bunches led to filtration losses of 5.2, 4.6, 4.2, 4, and 3.5ml, for each 2, 4, 6, 8, and 10 gr of additive. Meanwhile, the addition of industrial CMC led to filtration losses of 5, 4.1, 4, 3.7, and $3.4 \mathrm{ml}$, for each 2, 4, 6, 8, and 10 gr of additive, respectively. Therefore, an increase in the CMC content led to a reduction in filtration volume. A report by Al-Hameedi et al (2019) showed a $4.55 \mathrm{ml}$ reduction in mud filtrate volume obtained using 5 gr of CMC from carton waste and 4.5 gr of Na2C03. Thus, using $10 \mathrm{gr}$ and $20 \mathrm{gr}$ of CMC is bound to cause a further reduction in the mud filtrate volume, and consequently, lead to a lower loss circulation. 


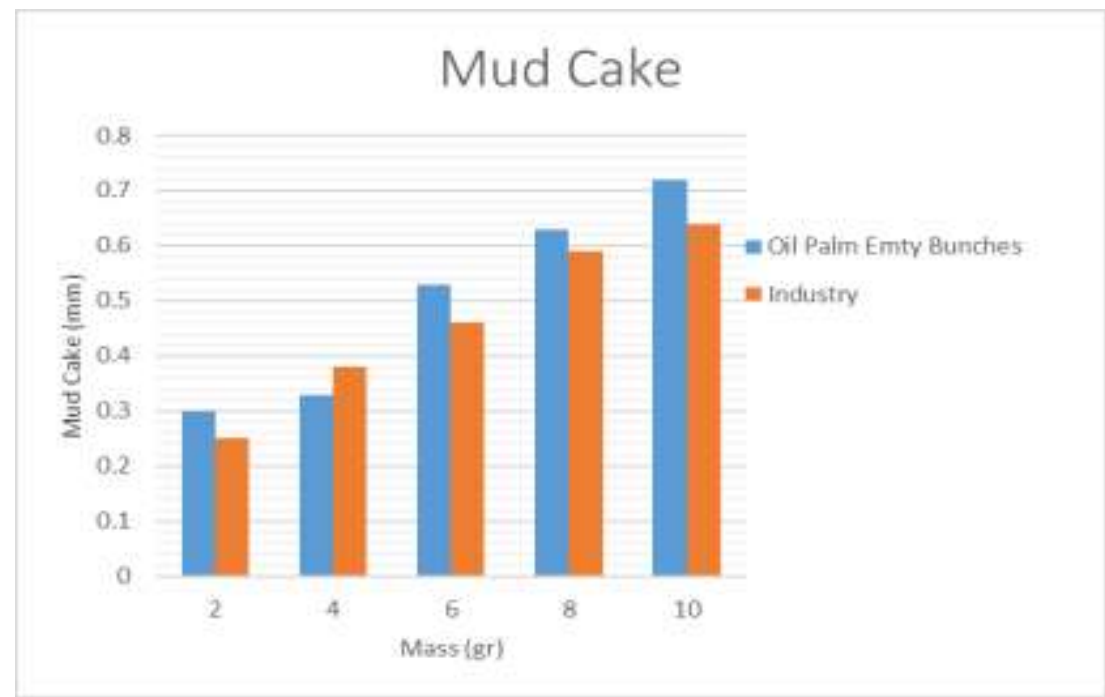

Figure 5. The mud cake charts of mud samples containing industrial CMC and CMC from empty oil palm fruit bunches.

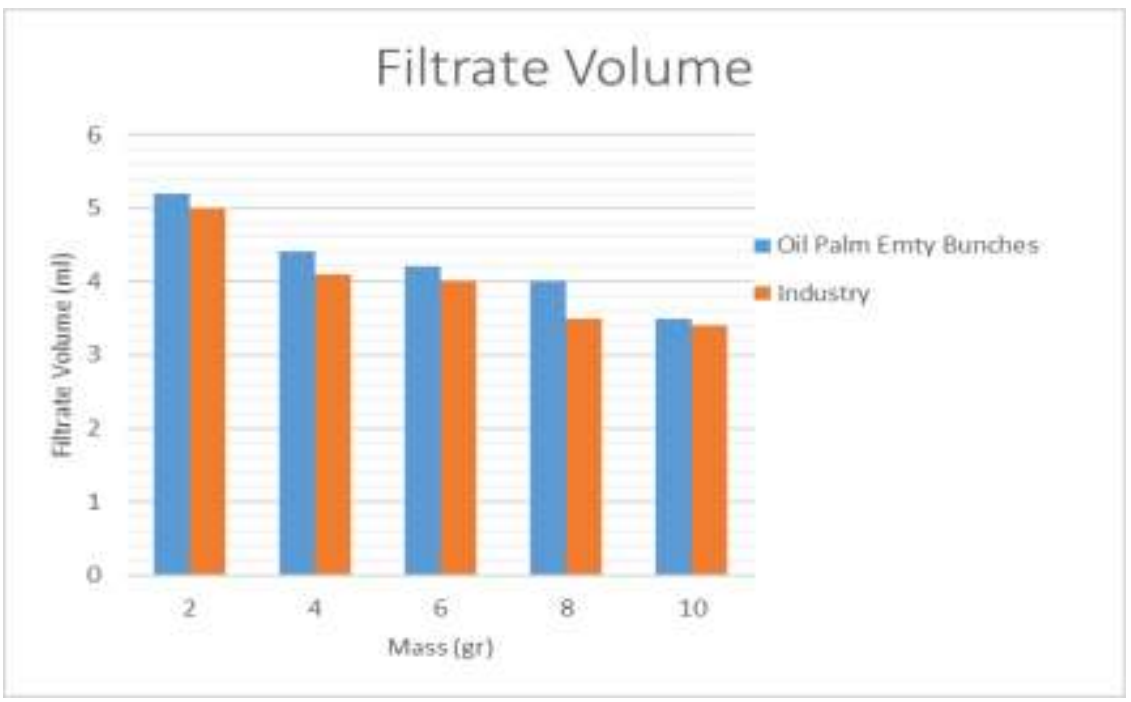

Figure 6. The filtration loss volume chart of mud samples containing industrial CMC and CMC from empty oil palm fruit bunches.

\section{CONCLUSION}

Based on the analysis of the viscosity, plastic viscosity, yield point and gel strength of drilling mud in this study, the addition of industrial CMC and CMC from empty oil palm fruit bunches both have a significant effect on the mud, where the change in rheological parameters increases linearly with CMC content. Therefore, CMC from empty oil palm fruit bunches was concluded to play a fairly good role in reducing loss circulation.

\section{ACKNOWLEDGEMENTS}

The authors are grateful to the Petroleum Engineering Drilling Laboratory and the Department of Petroleum Engineering, Universitas Islam Riau for providing the opportunity and permission to conduct experiments at the Drilling Laboratory.

\section{REFERENCES}

Ailin, A., Yarangga, C., Agus, D., \& Harjanto. (2017). Studi Grafit Berdasarkan Analisis Petrografi dan Sem/Edx pada Daerah WindesiKabupaten Teluk Wondama, Provinsi Papua. Prosiding Seminar Nasional XII “Rekayasa Teknologi Industri Dan Informasi 2017,” 185-191.

Al-Hameedi, A. T. T., Alkinani, H. H., Dunn-Norman, S., Alashwak, N. A., Alshammari, A. F., Alkhamis, M. M., Mutar, R. A., \& Ashammarey, A. (2019, June 3). Evaluation of environmentally friendly drilling fluid additives in water-based drilling mud. SPE Europec Featured at 81st EAGE Conference and Exhibition. 
https://doi.org/10.2118/195510-ms

Amin, V. M. I. P. Al. (2017). PrediksAmin, V. M. I. P. Al. (2017). Prediksi Kedalaman Lapisan Batuan Gamping Di Area Selat Sunda Utara Menggunakan Multilayer Perceptron Duelist Algortihm. 125. Retrieved from http://repository.its.ac.id/3890/i Kedalaman Lapisan Batuan Gamping Di Area S. 125.

Fatimah, T. (2016). Pemanfaatan Selulosa Dari Tandan Kosong Sawit Untuk Sintesis dan Karakterisasi Carboxymethyl Cellulose (CMC).

Gao, C. (2016). Potential Applications of Welan Gum in Upstream Petroleum Industry. International Journal of Oil, Gas and Coal Engineering, 4(2), 16. https://doi.org/10.11648/j.ogce.20160402.12

Grahadiwin, P., Zabidi, L., \& Rosidan, C. (2016). Studi Laboratorium Pengujian Fiber Mat sebagai Loss Circulation Materials Dan Pengaruhnya Terhadap Sifat Rheologi Lumpur Berbahan Dasar Minyak. Angewandte Chemie International Edition, 6(11), 951-952., 1-11.

Hall, L. J., Deville, J. P., Araujo, C. S., Li, S., \& Rojas, O. J. (2017). Nanocellulose and Its Derivatives for HighPerformance Water-Based Fluids. Proceedings - SPE International Symposium on Oilfield Chemistry, 2017-April, 561-574. https://doi.org/10.2118/184576-MS

Harry, T. F., Oduola, K., Ademiluyi, F. T., \& Joel, O. F. (2017). Application of Starches from Selected Local Cassava (Manihot Exculenta Crantz) as Drilling Mud Additives. American Journal of Chemical Engineering. Special Issue: Oil Field Chemicals and Petrochemicals, 5(1), 10-20. https://doi.org/10.11648/j.ajche.s.2017050301.12

Herawati, I., \& Rita, N. (2017). Studi Laboratorium Pemanfaatan Abu Ampas Tebu Untuk Peningkatan Strength Semen Pemboran. Jurnal Teknologi Minyak Dan Gas Bumi, 14, 47-54.

Hong, K. M. (2013). Preparation and characterization of magadiite. Kuei Suan Jen Hsueh Pao/Journal of the Chinese Ceramic Society, 41(12), 1704-1708. https://doi.org/10.7521/j.issn.0454-5648.2013.12.18

Inemugha, 0., Chukwuma, F., Akaranta, O., \& Ajienka, J. A. (2019, August 5). Rheological properties of terminalia mantaly exudate as drilling mud additive. SPE Nigeria Annual International Conference and Exhibition. https://doi.org/10.2118/198827-MS

Kafashi, S., Rasaei, M., \& Karimi, G. (2017). Effects of sugarcane and polyanionic cellulose on rheological properties of drilling mud: An experimental approach. Egyptian Journal of Petroleum, 26(2), 371-374. https://doi.org/10.1016/j.ejpe.2016.05.009

Luqman Arif, Aris Buntoro, Sudarmoyo, R. R. R. S. (2001). Penelitian Sifat-Sifat Rheologi Lumpur Filtrasi Rendah. Journal Proceding Simposium Nasional IATMI, 67, 3-5.

Maulana, B. (2017). Pengaruh pemakaian konsentrasi k-soltex dan bore trole terhadap sifat rheologi lumpur sistem kc1 polimer pada pengujian di laboratorium Universitas Trisakti. SKRIPSI-2015.

Richana, N., Prastowo, B., Purwantana, B., \& Nuralamsyah, A. (2011). Diversifikasi Tandan Kosong Kelapa Sawit Untuk Biofuel Generasi 2 untuk Reduksi 3 MCPD.

Rubiandini, R. (2010). Lumpur Pemboran. In Teknik Pemboran dan Praktikum. Institut Teknologi Bandung. 